\title{
Accessibility of registration offices for births and deaths: Red Sea Governorate, Egypt
}

Nesma Lotfy ${ }^{1}$

${ }^{1}$ Department of Biostatistics, High Institute of Public Health, Alexandria University, Alexandria, Egypt. (Correspondence to: Nesma Lotfy: califora9@ gmail.com).

\begin{abstract}
Background: Frontier governorates in Egypt have widely dispersed residential areas, which may make birth/death registration difficult for people because of the distance to registration offices.

Aims: This study aimed to assess the accessibility of birth/death registration offices in the Red Sea Governorate, one of Egypt's frontier governorates.

Methods: OpenStreetMap was used to locate residential areas and road networks of the Red Sea Governorate. Buffer analysis, with a radius of $20 \mathrm{~km}$ around registration offices, was done to assess the coverage. Network analysis was also conducted to calculate the distance between residential areas and registration offices. All spatial analysis work was done using ArcGIS 10.1 software.

Results: On delineating the areas of the Red Sea Governorate, 73 residential areas were identified (eight cities, 12 main villages and 53 residential areas outside of the cities and villages). Buffer analysis showed that even a $20 \mathrm{~km}$ buffer was not enough to cover all the residential areas. All cities had a good accessibility to registration offices compared with main villages (e.g. $1.5 \mathrm{~km}$ compared with $104.5 \mathrm{~km}$ ), although two main villages had a good accessibility $(0.2 \mathrm{~km}$ and $0.4 \mathrm{~km})$ as the registration offices were in the villages. For all 73 residential areas, the median distance was $37.6 \mathrm{~km}$ with $60.65 \mathrm{~km}$ interquartile range.

Conclusions: Residential areas in the Red Sea Governorate have varying levels of accessibility to birth/death registration offices. New registration techniques are suggested to improve accessibility to birth/death registration.

Keywords: civil registration, spatial analysis, Red Sea, Egypt

Citation: Lotfy N. Accessibility of registration offices for births and deaths: Red Sea Governorate, Egypt. East Mediterr Health J. 2022;28(4):266-271. https://doi.org/10.26719/emhj.22.032

Received: 11/10/20; accepted: 06/10/21

Copyright @ World Health Organization (WHO) 2022. Open Access. Some rights reserved. This work is available under the CC BY-NC-SA 3.0 IGO license (https://creativecommons.org/licenses/by-nc-sa/3.o/igo)
\end{abstract}

\section{Introduction}

The United Nations has defined the civil registration as the "universal, continuous, permanent, and compulsory recording of occurrence and characteristics of vital events (births, deaths, and other civil status events) occurring within the boundaries of a country based on the country's legal requirements". Vital statistics are "the collection of statistics on vital events in a lifetime of a person as well as relevant characteristics of the events themselves and of the person and persons concerned" (1).

The main aim of the civil registration and vital statistics system is to have complete registration of births, deaths and other civil status events and the generation of records from which vital statistics can be produced (2). Therefore, regular monitoring is needed of the extent to which civil registration systems are accessible and complete. Access to registration is however complex and covers a range of issues including the availability of registration points, the distance to be travelled, affordability, and cultural and social acceptability (3).

Limited accessibility to birth/death registration offices is an important impediment to the improvement of coverage and effectiveness of civil registration and, consequently, the quality and coverage of vital statistics (4). Therefore, the main goal of the operations of the civil registration system is to reach the lowest geographical level whereby the service point is within reasonable reach of households and individuals who have experienced events that need to be registered. It is therefore necessary that the assessment must be conducted at the municipal division level of government and the community level (2). The author of this paper undertook this project to assess the current status of civil registration and vital statistics in Egypt. The project has two objectives: (i) to calculate the completeness of death registration in Egypt (5), and (ii) to assess the accessibility of birth/death registration offices. The main aim of the current study was to assess the accessibility of birth/death registration offices in the Red Sea Governorate, one of Egypt's frontier governorates, using buffer analysis and network analysis.

\section{Methods}

\section{Study area}

The Red Sea Governorate, which is the longest governorate in Egypt, is located between the Nile and the Red Sea in the south-east of Egypt and covers an area of 203685 
$\mathrm{km}^{2}(6)$. All its cities and most of its villages lie directly on the Red Sea and are within about $108 \mathrm{om}^{2}$ of it. The governorate consists of the capital the city of Al-Ghurdaqah (Al-Ghurdaqah 1 and Al-Ghurdaqah 2) in addition to six other cities (Ras Gharib, Safaja, Al-Qusayr, Mersa Alam, Ash-Shalatin and Halayib). There are also 12 main villages (Az-Zafaranh, Wadi Dar Al Zaraey, Oum El-Hwytat, ElNasr, El-Hamraween, Abu Ghosoun, El-Sheikh El-Shazly, Berenice, Marsa Hamira, Abraq, Abu Ramad and Ras Hadraba) (7).

\section{Data preparation}

\section{Residential areas}

Data from OpenStreetMap (OSM) (8) was downloaded to obtain the residential areas of the Red Sea Governorate in 2019. Residential areas were classified as neighbouring houses as well as hotels (excluding military and industrial areas). The residential areas were established in two phases: first, using OSM residential area polygons and second, by tracing areas around those polygons. Almost all residential areas were determined using these two phases. Residential areas that were within $2 \mathrm{~km}$ of each other were aggregated. The population of the Red Sea Governorate was taken from the Central Agency for Public Mobilization and Statistics 2018 (9).

\section{Birth/death registration offices}

The website of the Ministry of Planning Monitoring and Administrative Reform was used to retrieve a list of birth/ death registration offices in the Red Sea Governorate (10). The Governorate has 10 birth/death registration offices, eight of which are located in urban areas: Ras Gharib, Al-Ghurdaqah, El-Meenaa, Safaja, Al-Qusayr, Mersa Alam, Ash-Shalatin and Halayib. The remaining two are located in rural areas: El-Hamraween and Oum ElHwytat. The coordinates of each registration office were found through Google Maps.

\section{Building network datasets}

The Red Sea road network data was also downloaded from OpenStreetMap (8). The OpenStreetMap toolbox for creating a network dataset was used to generate Red Sea network datasets. The network has the following properties: any vertex connectivity policy and (from end to end) elevation. ArcGIS 10.1 software was used for all data preparation (11).

\section{Network analysis}

Buffer analysis (12) and closest facility analysis (13) were performed as accessibility measuring techniques. The road network analysis was run using ArcGIS Network Analyst Extension.

\section{Buffer analysis}

A buffer zone is an area of a specified radius drawn around one or more map elements. It was run to identify the coverage of birth/death registration offices within the study area. A buffer of $20 \mathrm{~km}$ radius was created around each registration office. It should be noted that part of the buffer was eliminated because it crossed the sea.

\section{Closest facility analysis}

A closest facility analysis based on travel time was conducted to calculate the distance between the nearest registration offices and the residential areas. Thus, the residential areas were transformed to a central point using the Feature to point tool in ArcGIS from data management tools.

\section{Results}

After tracing residential areas and conducting $2 \mathrm{~km}$ aggregation, 73 residential areas were found (eight cities, 12 main villages and 53 residential areas outside of the cities and towns). Almost all residential areas were located along the coast of the Red Sea, as were the birth/death registration offices.

Buffer zone analysis for each birth/ death registration office within a radius of $20 \mathrm{~km}$ showed that many residential areas were not included in any buffer. In addition, there was high overlap between Al-Ghurdaqah and El-Meenaa buffers, and slight overlap between Oum El-Hwytat and Safaja buffers, and El-Hamraween and AlQusayr buffers.

Table 1 shows the shortest distance from the eight cities and 12 main villages to a birth/death registration office and their mid-year populations in 2018.

All cities with a large population (>3000) had a high level of accessibility to a registration office (Ras Gharib $1.5 \mathrm{~km}$, Al-Ghurdaqah $116.7 \mathrm{~km}$, Al-Ghurdaqah $212.4 \mathrm{~km}$, Safaja $5.5 \mathrm{~km}$, Al-Qusayr $3.4 \mathrm{~km}$, Mersa Alam $2.5 \mathrm{~km}$, Ash-Shalatin $4.6 \mathrm{~km}$ and Halayib; $1.8 \mathrm{~km}$ ). In contrast, most of the main villages had a low level of accessibility to urban registration offices (El-Sheikh El-Shazly $152.8 \mathrm{~km}$, Berenice $110.8 \mathrm{~km}$, Az-Zafaranh $104.5 \mathrm{~km}$, Abraq $86.7 \mathrm{~km}$, Abu Ghosoun $80.9 \mathrm{~km}$, El-Nasr $78.7 \mathrm{~km}$, Marsa Hamira 46.7 km, Wadi Dar Al Zaraey 46.5 km, Abu Ramad $42.7 \mathrm{~km}$ and Ras Hadraba $16.3 \mathrm{~km}$ ). Two villages Oum El-Hwytat and El-Hamraween had a high level of accessibility (0.2 km and $0.4 \mathrm{~km}$ respectively) to only two rural registration offices as these offices are located in the villages. One village (Berenice) has to go to another municipal divisions (Ash-Shalatin) to register vital events. For all 73 residential areas, the median distance was $37.6 \mathrm{~km}$ with $60.65 \mathrm{~km}$ interquartile range.

Table 2 shows the mean distances from the central point of the remaining 53 residential areas or hotels to the nearest registration office. In Ras Gharib, 12 residential areas were dispersed over the area. However, the mean (standard deviation (SD)) of the shortest distance of those residential areas to Ras Gharib registration office was $74.93(36.01) \mathrm{km}$. In comparison, Halayib has three residential areas with a mean distance of $21.70(10.00) \mathrm{km}$ to the Halayib registration office. In some areas of Al-Qusayr, Mersa Alam and Ash-Shalatin municipal divisions, the shortest distance is to a registration office that belongs to another municipal division.

Table 3 shows the number of residential areas serviced by registration offices. Oum El-Hwytat and El- 


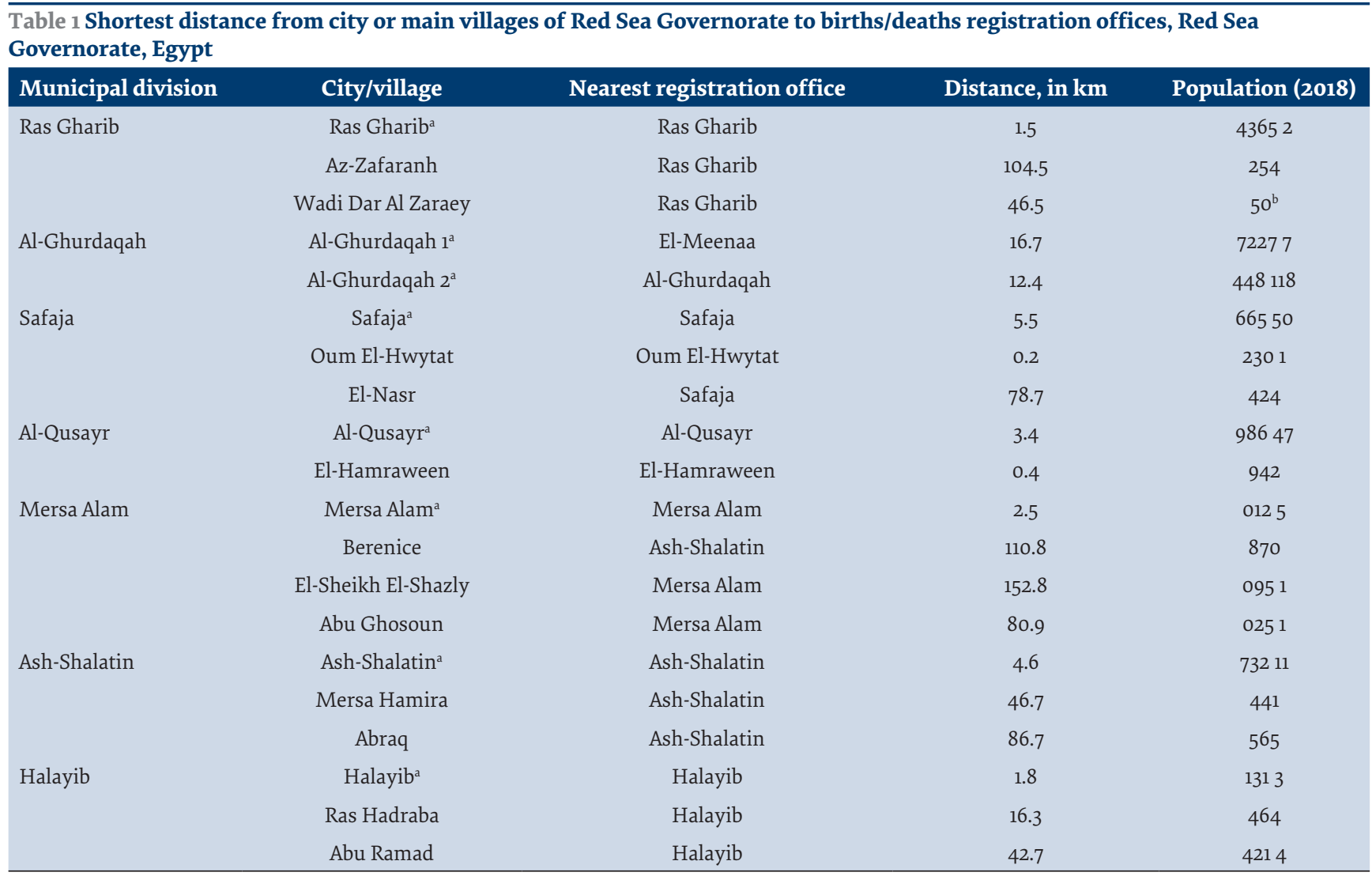

${ }^{a}$ City; ${ }^{b} 2016$.

Hamraween registration offices have the lowest service load, while Ras Gharib and Mersa Alam registration offices have the largest service load.

\section{Discussion}

This study addressed the second objective of the project assessing the current status of civil registration and vital statistics in Egypt. The first objective was to calculate the completeness of death registration in Egypt. In the Red Sea Governorate, the completeness of death registration was $92.9 \%-95.8 \%$ for urban areas and 3.7\% for rural areas. (5) Since the completeness of death registration in rural areas is very low, the second objective was developed to evaluate the accessibility to birth/death registration offices in the Red Sea Governorate.
It is likely that the greater the distance to the registration office, the less the opportunity and the more the travel costs for citizens and this can cause a reduction in the registration rate. An area is considered as having a good access if it is located within $4-5 \mathrm{~km}$ of a facility and as fairly inaccessible if located within $10 \mathrm{~km}$. (14) In our case, the buffer analysis showed that even $20 \mathrm{~km}$ was not enough to cover all the residential areas (most of residential areas were not included within the buffer). Despite this, there was a high overlap between some buffers such as Al-Ghurdaqah and El-Meenaa buffers. In addition, there were wide gaps between some registration office buffers such as Al-Qusayr, Mersa Alam and AshShalatin registration offices although there are many residential areas in between these municipal divisions.

\begin{tabular}{|c|c|c|c|}
\hline Municipal division & Areas, no. & Nearest registration office & Mean (SD) distance, in km \\
\hline Ras Gharib & 12 & Ras Gharib & $74.93(36.01)$ \\
\hline Al-Ghurdaqah & 4 & El-Meenaa, Al-Ghurdaqah & $52.25(30.60)$ \\
\hline Safaja & 4 & Safaja & $71.17(3.23)$ \\
\hline Al-Qusayr & 13 & Oum El-Hwytat, Al-Qusayr, El-Hamraween & $23.60(13.90)$ \\
\hline Mersa Alam & 13 & Mersa Alam, Ash-Shalatin, Al-Qusayr & $61.47(34.70)$ \\
\hline Ash-Shalatin & 4 & Ash-Shalatin, Halayib & $42.10(34.60)$ \\
\hline Halayib & 3 & Halayib & $0(10.00)$ \\
\hline
\end{tabular}




\begin{tabular}{lcccc}
\hline Table 3 Cities, main villages and residential areas served by registration offices by municipal division, Red Sea Governorate, Egypt \\
$\begin{array}{lccc}\text { Municipal division } \\
\text { Registration office }\end{array}$ & $\begin{array}{c}\text { No. of cities served } \\
\text { Ras Gharib }\end{array}$ & Ras of main villages served & $\begin{array}{c}\text { No. of residential area } \\
\text { served }\end{array}$ \\
Al-Ghurdaqah & Al-Ghurdaqah & 1 & 2 & 12 \\
& El-Meenaa & 1 & 0 & 2 \\
Safaja & Safaja & 1 & 0 & 2 \\
& Oum El-Hwytat & 1 & 1 & 4 \\
Al-Qusayr & Al-Qusayr & 1 & 0 & 5 \\
& El-Hamraween & 0 & 1 & 1 \\
Mersa Alam & Mersa Alam & 1 & 2 & 10 \\
Ash-Shalatin & Ash-Shalatin & 1 & 3 & 4 \\
Halayib & Halayib & 1 & 2 & 5 \\
\hline
\end{tabular}

Of the 73 residential areas, 53 were not considered cities or main villages, and most of these were located along the coast of the Red Sea. In each municipal division, the mean distance from those residential areas to the nearest registration office was calculated, and long distances were found in almost all municipal divisions except Halayib (21.70 km (10.00)) and Al-Qusayr (23.60 km (13.90)) because Halayib had four residential areas and AlQusayr had three registration offices near its residential areas with one of them belonging to Safaja municipal division (Oum El-Hwytat registration office).

Three municipal divisions - Al-Qusayr, Mersa Alam, and Ash-Shalatin-have their nearest registration office in another municipal division. As a result some registration offices will have work overload compared with others. It is advisable to register births and deaths in the municipal division in which individuals live (5).

Regarding serviced areas, two registration offices in urban areas serviced many areas: Ras Gharib (one city, two main villages and 12 residential areas) and Mersa Alam (one city, two main villages and 10 residential areas). In addition, the distances travelled to these registration offices from main villages and residential areas were considerable. These registration offices may need support to overcome to these issues.

Poor accessibility to birth/death registration offices in rural areas is considered to be a cause of low completeness registration. As there are only two registration offices in rural areas in the Red Sea Governorate, almost all villages will register at other registrations located in urban areas. study has some limitations. Data about residential areas and road networks may be not precise. Furthermore, the study focused on only one governorate (the Red Sea Governorate), and more governorates should be investigated.

The residential areas in the Red Sea Governorate have varying levels of accessibility to birth/death registration offices. Increasing the number of registration offices is not necessarily an appropriate solution in this situation (5) because of the low population levels in the villages. Therefore, there is a need for a new and robust system to register births and deaths such as mobile registration.

Mobile services have been established by the Office of Population Registration in Aceh, Indonesia in the districts of Pangkajene and Kepulauan since 2009 to provide services for civil registration and administrative documentation to remote communities, including birth certificates, family cards and identification cards (15). This policy has been successful with village officials, who consistently ranked mobile services among the top three priorities for improving civil registration coverage. Moreover, bringing registration services closer to communities is a way of increasing ownership of the certificate.

Mobile registration in villages and delegation of authority for civil registration to the subdistrict level could be strategies to meet the demand for birth certificates and other civil registration documents in Egypt.

Funding: None.

Competing interests: None declared. 


\section{Accessibilité des bureaux d'enregistrement des naissances et des décès : Gouvernorat de la mer Rouge (Égypte)}

\section{Résumé}

Contexte : Les gouvernorats d'Égypte qui sont en bord de frontières comportent des zones résidentielles largement dispersées, ce qui peut rendre l'enregistrement des naissances et des décès difficile pour les personnes en raison de la distance qui les sépare des bureaux d'enregistrement.

Objectifs : La présente étude visait à évaluer l'accessibilité des bureaux d'enregistrement des naissances et des décès dans le Gouvernorat de la mer Rouge, l'un des gouvernorats de l'Égypte qui sont en bord de frontières.

Méthodes : OpenStreetMap a été utilisé pour repérer les zones résidentielles et les réseaux routiers du Gouvernorat de la mer Rouge. Une analyse des zones tampons, dans un rayon de $20 \mathrm{~km}$ autour des bureaux d'enregistrement, a été effectuée pour évaluer la couverture. Une analyse de réseau a également été réalisée pour calculer la distance entre les zones résidentielles et les bureaux d'enregistrement. Tous les travaux d'analyse spatiale ont été effectués à l'aide du logiciel ArcGIS 10.1.

Résultats: Lors de la délimitation des zones du Gouvernorat de la mer Rouge, 73 zones résidentielles ont été identifiées (huit villes, 12 villages principaux et 53 zones résidentielles ne faisant pas partie des villes et des villages). L'analyse des zones tampons a montré que même un tampon de $20 \mathrm{~km}$ n'était pas suffisant pour couvrir toutes les zones résidentielles. Toutes les villes avaient une bonne accessibilité aux bureaux d'enregistrement par rapport aux villages principaux (par exemple, 1,5 km par rapport à $104,5 \mathrm{~km})$, même si deux villages principaux avaient une bonne accessibilité $(0,2 \mathrm{~km}$ et $0,4 \mathrm{~km})$ car les bureaux d'enregistrement étaient dans les villages. Pour les 73 zones résidentielles, la distance médiane était de $37,6 \mathrm{~km}$ avec un intervalle interquartile de 60,65 km.

Conclusions : Les zones résidentielles du Gouvernorat de la mer Rouge ont une accessibilité plus ou moins grande pour les bureaux d'enregistrement des naissances et des décès. De nouvelles techniques d'enregistrement sont proposées pour améliorer l'accessibilité à l'enregistrement des naissances et des décès.

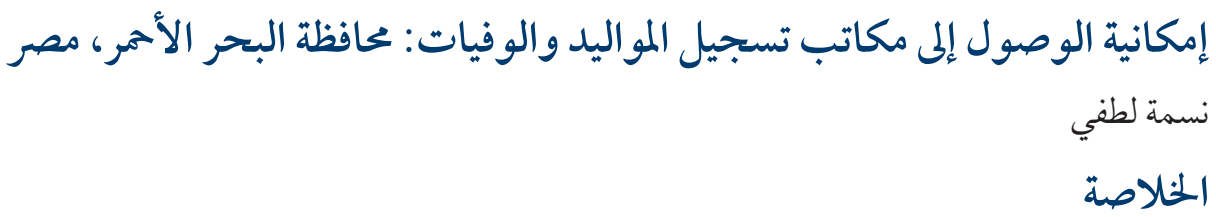

الخلفية: تتسم المحافظات الحدودية في مصر بوجود مناطق سكنية متفرقة على نطاق واسع، وهو ما قد يجعل من الصعب على الناس تسجيل المو اليد/

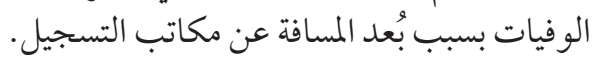

الأهداف: هدفت هذه الدراسة إلى تقييم إمكانية الوصول إلى مكاتب تسجيل المو اليد/ الوفيات في محافظة البحر الأحمر، وهي إحدى المحافظات الحدودية في مصر.

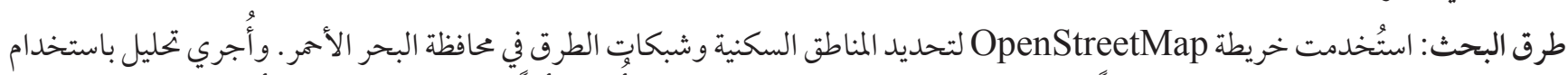

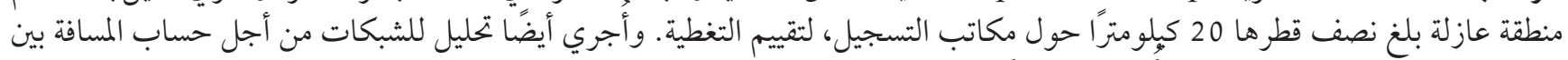

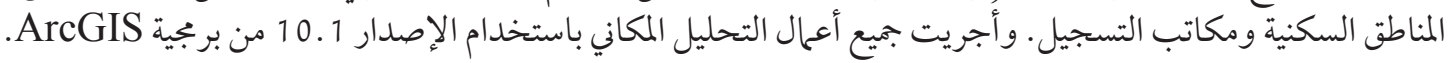

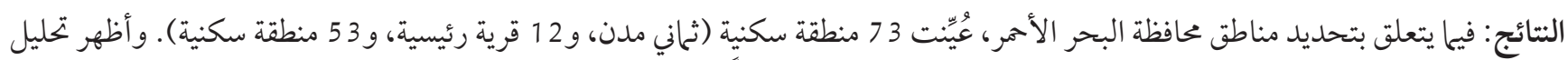

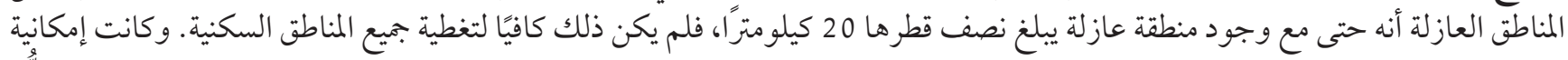

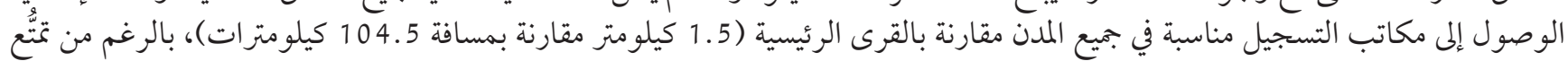

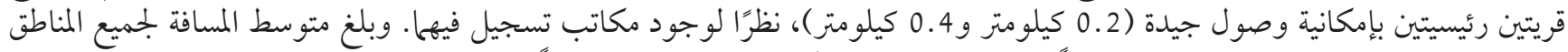

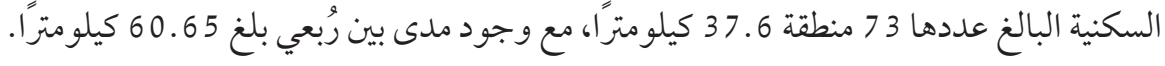

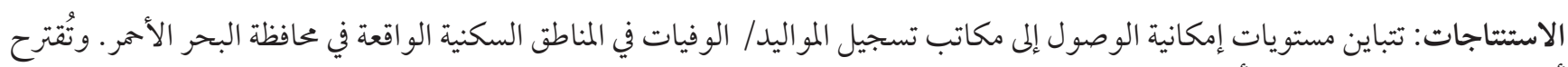

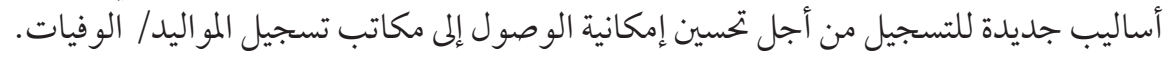




\section{References}

1. Department of Economic and Social Affairs. Principles and recommendations for a vital statistics system. Revision 3. New York, NY: United Nations Department of Economic and Social Affairs; 2014 (https://unstats.un.org/unsd/demographic/standmeth/ principles/m19rev3en.pdf, accessed 15 December 2021).

2. Improving national civil registration and vital statistics systems in Africa, Volume 1. Guidelines for conducting comprehensive assessments of national systems. New York, NY: United Nations Economic Commission for Africa (https://archive.uneca.org/ sites/default/files/uploaded-documents/Statistics/CRVS/crvs_assessment_guidelines_volume1_en.pdf, accessed 15 December 2021).

3. Strengthening civil registration and vital statistics for births, deaths and causes of death: resource kit. Geneva: World Health Organization; 2013 (https://apps.who.int/iris/handle/10665/78917, accessed 15 December 2021).

4. Status of civil registration and vital statistics: African English speaking countries. New York, NY: United Nations Statistics Division Demographic Statistics; 2016 (Demographic Statistics CRVS Technical Report Series, Vol. 3; https://unstats.un.org/unsd/ demographic-social/crvs/documents/Technical-report-CRVS-in-English-speaking-African-countries3.pdf, accessed 15 December 2021).

5. Lotfy N. Spatial analysis of completeness of death registration in Egypt. J Egypt Public Health Assoc. 2020;95(1):12.

6. The Red Sea Governorate [website]. 2020 (http://www.redsea.gov.eg/t/default.aspx, accessed 1 April 2020.

7. Gaber SM, Aly SM, Masood KA. [Center of information and decision on making, Red Sea Governorate achievement index]. Cairo: Dar El-Maref Publishing; 2010 [In Arabic].

8. OpenStreetMap Wiki. Main Page. Wiki; 2014 (https://wiki.openstreetmap.org/w/index.php?title=Main_Page\&oldid=1060762, accessed 1 April 2020).

9. Population. Cairo: Central Agency for Public Mobilization and Statistics; 2018 (https://www.capmas.gov.eg/, accessed 11 December 2020).

10. Rate your services and improve your life. Cairo: Ministry of Planning Monitoring and Administrative Reform; 2018 (http://www. rateyourservices.gov.eg/, accessed 4 April 2020).

11. ArcGis E. 10.1 Software and user manual. West Redlands, CA: Environmental Systems Research Institute; 2007.

12. Arc Map. Buffer. West Redlands, CA: Environmental Systems Research Institute; 2016 (https://desktop.arcgis.com/en/arcmap/10.3/tools/analysis-toolbox/buffer.htm, accessed 1 April 2020).

13. Arc Map. Closest facility analysis. West Redlands, CA: Environmental Systems Research Institute; 2016 (https://desktop.arcgis. com/en/arcmap/latest/extensions/network-analyst/closest-facility.htm, accessed 1 April 2020).

14. Abass AM. Locational and coverage analysis of the vital registration centers Gombe State, Nigeria. IOSR J Environ Sci Toxicol Food Technol. 2014;8(1):79-88.

15. Kusumaningrum S, Bennouna C, Siagian C, Agastya NLP. Back to what counts: birth and death in Indonesia. Jakarta: The Center on Child Protection Universitas Indonesia (PUSKAPA) in collaboration with the Ministry of National Development Planning (BAPPENAS) and Kolaborasi Masyarakat dan Pelayanan untuk Kesejahteraan (KOMPAK); 2016. 